\title{
Formation of translation competence in future vocational specialists: a systematic review
}

\section{Formación de la competencia traductora en futuros especialistas vocacionales: una revisión sistemática}

\author{
DUDINA, Oksana ${ }^{1}$ \\ HOLOVKO, Iryna ${ }^{2}$ \\ CHERNYSHENKO, Iryna ${ }^{3}$
}

\begin{abstract}
The integration of Ukrainian national higher education system into the global higher education and research space requires targeted reform of higher education in order to ensure its competitiveness. The priority of the development of higher education in Ukraine is the training of highly qualified, professionally competent professionals who are capable of self-realizing in the modern information society, are ready for continuous improvement and professional self-development. Modern scientific and technological progress is necessary for the socio-economic and cultural development of humankind, and its achievements must be available for use by representatives of different languages and cultures. An important role of technical translation specialists is to ensure access to modern advanced scientific and technical knowledge from around the world without language barriers. Thus, the issue of professional training of highly qualified, competitive and intellectually developed specialists in technical translation in the world and, in particular, in Ukraine becomes especially relevant. The scientific, technical and economic potential of the United States as a highly developed country has led to interest in studying the experience of this leading country in higher education in the training of technical translators in high-ranking US universities. Key words: vocational translation, technical translation, preparedness, US Universities, masters.

\section{Resumen}

La integración del sistema nacional de educación superior ucraniano en el espacio global de educación superior requiere una reforma dirigida de la educación superior para esencializar su competitividad. La prioridad del desarrollo de la educación superior en Ucrania es la capacitación de profesionales altamente calificados y profesionalmente competentes que son capaces de realizar auto-realización en la sociedad de la información moderna, están listos para la mejora continua y el desarrollo propio profesional. El progreso científico y tecnológico moderno es necesario para el desarrollo socioeconómico y cultural de la humanidad, y sus logros deben estar disponibles para su uso por representantes de diferentes idiomas y culturas. Un papel importante de los especialistas en traducción técnica es garantizar el acceso a los conocimientos científicos y técnicos avanzados modernos de todo el mundo sin barreras lingüísticas. Por lo tanto, el tema de la capacitación profesional de especialistas altamente calificados, competitivos e intelectualmente desarrollados en la traducción técnica en el mundo y, en particular, en Ucrania se convierte especialmente. El potencial científico, técnico y económico de los Estados Unidos Ilevó a interesarse al estudiar la experiencia de este país líder en educación superior en universidades estadounidenses de alto rango. Palabras clave: traducción vocacional, traducción técnica, preparación, universidades estadounidenses, maestros.
\end{abstract}

\footnotetext{
${ }^{1}$ Ph.D., Donetsk National Medical University, Kropyvnytskyi, Ukraine, email: Rexiff@ukr.net

${ }^{2}$ Senior Lecturer, Ph.D.,Central Ukrainian National Technical University, Kropyvnytskyi, Ukraine, email: irinagolovko@gmail.com

3 Ph.D., Candidate of Sciences (in Pedagogy), Applied and General Linguistics. Department in Volodymyr Vynnychenko Central Ukrainian State Pedagogical University, Kropyvnytskyi, Ukraine, email: chernyshenko.iryna@gmail.com
} 


\section{Introduction}

The issue of training highly qualified, competent specialists in technical translation in the system of vocational education in Ukraine is not sufficiently studied and covered in domestic pedagogy, so the main and necessary resource for establishing modern directions of professional education of technical translators is the assimilation and adaptation of such training abroad.

The Law of Ukraine "On Higher Education" (2014) defines "ways to reform higher education in the context of Ukraine's integration into the European Higher Education Area, where domestic higher education needs to rethink the traditions associated with the modernization of master's programs in accordance with modern social requirements" [9].

Analysis of American research shows that professionalism is a basic concept in the theory and practice of vocational translator. The unprofessionalism of any translator, especially technical, causes significant damage, and sometimes even threatens the existence of the organization. The activities of a vocational translation specialist as a professional are based on the following general criteria.

1. To have ethical knowledge and apply it successfully. American scholar M. Tennett gives "this condition the highest status in the translator's code of conduct, they are often deal with confidential information, such as: business plans, marketing strategies or inventions and should never use this knowledge if it will harm the client; a vocational translator, showing honesty and dedication, must build a favorable relationship with his clients based on trust, so he should never take a translation job that goes beyond their professional capabilities" [8].

2. To have advanced knowledge of the language of translation. "A technical translation specialist masters the original language and the language into which he translates at a high level, and modern knowledge in the field of engineering in order to transfer the necessary information into a clear and understandable way. A specialist has also to be sufficiently familiar with the subject or field of translation to make a high-quality translation [8].

3. To have the ability for self-improvement throughout life and use research competence in activities. "A technical translation specialist has the potential for lifelong learning and is ready to adapt to the rapidly changing conditions of the modern technological world, so a technical translator also masters modern means of communication, successful use of modern technologies, in particular, vocational translators should never think of stopping the learning and self-improvement process" [8].

\section{Methodology}

To achieve the goal and perform the tasks of research a set of the following methods was used:

- analysis, generalization, content analysis - to determine the state of research problem development in pedagogical, scientific and methodological works of domestic and foreign scientists, in strategic and regulatory documents and in information resources;

- comparison, interpretation, classification, systematization - to identify leading trends and features in the professional higher education of vocational translators in the United States, to identify and characterize the main approaches, forms, methods and content ofvocational translating training in US universities;

- statistical analysis, generalization - to draw conclusions, identify fundamental and practical components in vocational translators training in US higher education system, as well as to assess the state of training of technical translation specialists in the US and Ukraine and working out recommendations for the development of such training in Ukraine; 
- conversation, observation, survey, discussion of topical issues during conferences, discussions with American teachers at international meetings - to obtain primary empirical material to identify the features of the masters' training of vocational translation in US universities;

- modeling - to develop conceptual model of master's degree training in vocational translation in Ukraine.

The research was carried out on the basis of pedagogical works of Ukrainian, European and American scientists, as well as by studying the materials of conventions, laws and regulations of the Department of Education of the United States of America and the Ministry of Education and Science of Ukraine; educational programs for master's degrees in technical translation at US universities; electronic resources, periodicals ("Translation Journal", "The Journal of Specialized Translation" etc.) [2; 3].

The study of vocational translation specialists' training in the United States continued during 2013 - 2018. The scientific research included the following three stages: analytical and introductory, diagnostic and exploratory, conceptual and modeling.

Analytical and introductory stage (2013-2014): bibliographic search of primary and scientific information, collection of material, its systematization and classification, study and selection of documentary information, compilation of the list of processed sources, tasks setting, determination of the object and the subject and directions of research, writing abstracts, reports and speeches for scientific conferences. Based on the analysis, the current state of development of the theory and practice of translation training is substantiated and the relevance of the research is substantiated, the object, subject, purpose, tasks and methods, its methodological and theoretical principles, source base are determined, scientific novelty, theoretical and practical significance is revealed, scientific research results implementation.

Diagnostic and exploratory stage (2014-2016): choosing the directions of research, defining the main idea, research hypothesis, concretization the tasks and methods of research, writing the introduction of the thesis, terminological review of conceptual definitions of dissertation research, results of comparative analysis of theoretical and methodological approaches of domestic and foreign authors to the problem of master's degree in the US universities, analyzed the theory and practice of training masters in vocational translation in US establishments of higher education, studied the conditions for ensuring the quality of higher education in the training of technical translation and identified trends in research-oriented training of masters in technical translation in the United States.

Conceptual-modeling stage (2016-2018): identification the reasons of vocational translation development in Ukraine, substantiation of conceptual principles of professional training of masters of vocational translation in Ukrainian universities, characteristics of the main ways of using the experience of masters' professional training in technical translation. Based on the experience of master's training in the United States, the concept of forming the professional competence of a future vocational translation specialist. The study analyzed the main problems of vocational translation masters' training in Ukrainian universities and ways to solve them.

\section{Results}

The tendencies of master's vocational translation training in the United States are divided into national and regional. Extensive and successful improvement of modern advanced technologies creates a trend to borrow progressive world experience and implement standards of masters' professional education in sphere of translation.

Strategic areas of vocational translation masters' preparation at US universities are professional and research. The Vocational Master's program is worked out by leading translators-practitioners who are employees of 
international and domestic companies and institutions, and researchers who work in the field of technical translation, so students have the opportunity to receive professional training based on practical experience and scientific achievements of leading translators. This makes it possible to ensure the relevance and effectiveness of the curriculum.

According to S. Shandruk: "the main feature of the training content in US universities is the interaction of different approaches, concepts, models, so in the practice of modern higher professional education in the US there are the following paradigms: behavioral, personal, constructive and reflexive, the unifying factor of which is the idea of the importance of humanitarian education, and the difference is in the different views of the problem of organizing the process of vocational training... " [7].

The goals of the Master's program in vocational translation in the United States show a common goal in the content of education - the development of professional competencies, mastering the best practices of technical translation in a growing global economy. Learning objectives are fully integrated with the content of education in the preparation of masters in technical translation. The curriculum is divided into three parts: the theory of translation and language; disciplines of specialization; practical translation. The curriculum includes normative (compulsory) and elective (at the student's choice) disciplines. The aims of vocational translators' curriculum in the United States are to provide future specialists with high-quality foreign language knowledge, taking into account previously acquired special skills and using advanced methods and state information technology tools. Students have the opportunity to master the disciplines on a full-time or distant basis. As part of the specialization of vocational translation master's program, there are software applications which allow you to perform individual complex tasks and participate in team projects.

The implementation of innovative technologies of vocational translation masters' training in the United States makes it possible to train competitive professionals with a high level of qualification that meets the requirements of modern production. Focusing on the requirements of the international labor market and the need of American society for highly qualified technical translators, the US Free Economic Zone is developing and implementing new methods, forms and tools for teaching future vocational translators. In such educational process, a problemsolving methods predominate: problem-based presentation of material, partial-search, search and research. Since, there are full-time and distant form of education in the United States, E-learning is widely used. The main elements in the preparation of masters in technical translation in the United States are creativity, practical orientation and problem-solving presentation of the material.

When it comes to the implementation of the communicative approach, researchers normally focus on 6 major principles of organizing student learning activity, which are as follows:

1) the principle of organizing learning activity in a communicative person-oriented fashion;

2) the principle of mandatory use and rational combination of algorithmic heuristic learning activities as part of teaching verbal comunication;

3) the principle of arranging collective learning activities in classes attended by the entire language student group with a view to cultivating relevant skills and proficiencies;

4) the principle of teaching the various types of speech activity in an interlinked fashion factoring in their characteristics and using accelerated speech perception learning techniques;

5) the principle of arranging the learning process in a cyclic manner;

6) the principle of rational use of the native language in teaching a foreign one [1]. 
A defining feature of masters' professional training in the United States is the creation of favorable conditions for self-development and self-improvement of students through problem-based learning, cooperation of students and teachers, partnership with employers and implementation of the principles of differentiation and individualization. It was found that interactive, cooperative learning in cooperation is implemented in practice using such methods as the method of "mutual and individual learning", the method of "microphone", "jigsaw", studying in small groups, teamwork and pair work. The most common form of classes for future vocational translators is a lecture, during which there is an active discussion of current issues, search for information and interesting facts, appeal to the audience, exchange views to update cognitive activity, and create problem situations as a means of stimulating professional thinking. The development of the professional competence of a translator comes to the fore. Various methods of assessing the competencies of future masters in technical translation are used in US universities, focusing on learning outcomes. The main types of assessment are current assessment and examination assessment, the results of which affect the overall semester score.

Masters in Technical Translation at New York University during their studies "work on information and word selection, correct phrasing and editing, which is based on the analysis of documents, reports, news articles, descriptions and official letters". Training of specialists in technical translation involves mastering engineering disciplines. Educational services are provided by teachers who have experience in translation in a particular field [6].

Students' self-studying becomes an integral part of the educational environment and the main means of assimilation of educational material by students in time free from compulsory education. In US universities, independent work begins with the choice of topic and object of study. The student develops an original concept of interpretation of the material, which is not described in scientific or critical literature, and after analyzing scientific sources, archival data, primary documents, etc. conducts his own research using methods that reflect his original thinking.

An important part of a master's program is a thesis or research project. The research enables master to find ways to solve current problems of translation of technical texts or to implement creative projects.

According to the US Department of Education, the quality of translator training is a trend in the development of the system of masters' professional training. The state and society have their own requirements for American technical translators, which are highly qualified, have a bachelor's or master's degree in translation or a master's degree in technical knowledge. Therefore, every US university is trying to strengthen its credibility by referring to a large list of worldknown scientists and innovation managers who discuss events, seminars, and educate students.

It is justified that for ensuring the professional quality and effectiveness of Vocational Translation Masters' training is to develop an appropriate list of competencies, formulating learning outcomes. It is established that the Association for Accreditation of Postgraduate Education helps to improve the level of qualification in continuing higher education and checks the educational program for the quality of training in the specialty, accessibility of teaching materials, providing students with scientific and technical base and reputation of faculty. Every university in the United States seeks to supplement its reputation with a significant list of famous teachers, scientists and innovation managers who participate in discussions of events, seminars, and lecture instruction. It is established that masters of vocational translation in the United States have the opportunity to receive training that is based on the results of research and practical experience of leading translators and provides up-to-date relevance and effectiveness. 
Table 1

Comparative table of master's degrees in vocational translation in the United States

\begin{tabular}{|c|c|}
\hline $\begin{array}{c}\text { Name of High Educational } \\
\text { Establishment }\end{array}$ & Aims of Masters' Program \\
\hline $\begin{array}{l}\text { University of Illinois at } \\
\text { Urbana-Champaign }\end{array}$ & $\begin{array}{l}\text { Development of text analysis, interpretation and translation skills; mastering the } \\
\text { knowledge of the basic technical translation concepts; formation of knowledge on } \\
\text { technical translation and mastering new methods of technical translation and texts } \\
\text { interpretation (information technologies and means of automated translation); } \\
\text { preparation for the management of translation and interpretation techniques. }\end{array}$ \\
\hline James Madison University & $\begin{array}{l}\text { Development of language skills, including reading comprehension, summary and text } \\
\text { analysis; mastering the skills of working with monolingual and bilingual dictionaries and } \\
\text { electronic tools, developing skills in word processing and mastering several types of } \\
\text { translation; development of spelling skills, punctuation, syntax, semantics. }\end{array}$ \\
\hline $\begin{array}{l}\text { New York University School } \\
\text { of Continuing and } \\
\text { Professional Studies }\end{array}$ & $\begin{array}{l}\text { Development of the skills of exact and adequate translation of the technical text, basic } \\
\text { knowledge and skills of specialized terminology usage necessary for the conclusion of } \\
\text { economic agreements, books, articles, official documents, recommendations on global } \\
\text { trade, mechanical engineering; development the skills of complex technical text } \\
\text { translation with considerable volume; mastering the skills of using computer tools, to } \\
\text { translate definitions of terms, descriptions, instructions. }\end{array}$ \\
\hline Rose-Hulman Institute & $\begin{array}{l}\text { Mastering the scientific and technical vocabulary; development of skills of complex } \\
\text { grammatical structures usage; mastering translation methods for scientific and technical } \\
\text { texts; development of skills of independent work necessary for technical translation. }\end{array}$ \\
\hline $\begin{array}{l}\text { Babel University } \\
\text { Professional School of } \\
\text { Translation }\end{array}$ & $\begin{array}{l}\text { Development of skills and abilities necessary to work as an international paralegals } \\
\text { (paralegals - lawyer assistant); development of accurate and complete translation skills as } \\
\text { a professional translator specializing in the translation of legal documents, development } \\
\text { of skills and abilities to perform accurate and complete translation as a professional } \\
\text { translator specializing in the translation of patents, technical and medical documents, } \\
\text { skills development of literate, idiomatic and business translation. }\end{array}$ \\
\hline
\end{tabular}

Source: systematized by the authors on the basis of electronic resources [Electronic resources]. - Available at: http://illinois.edu, http://www.washington.edu, http://www.jmu.edu, http://www.miis.edu, http://www.scps.nyu.edu, http://www.babel.edu

There is a tendency to decentralize higher education and improve the quality education in process of vocational translators' training in the United States. This trend is reflected in academic freedom to develop and implement master's degree programs in vocational translation, to introduce professional specialties in vocational translators' training, on the other hand, the modernization of their assesment system is the responsibility of the state authorities, as well as the support of technical translators by raising the status of translators. It is established that an important task of US higher education is to increase the level of competence of future professionals and restore the value of higher education diplomas through the regulation of standards.

\section{Conclusion}

The role of vocational translation specialists in Ukraine is growing in conditions of intensive development of international cooperation with other countries. Domestic establishments of high education face the task of training highly qualified vocational translation specialists who have all the necessary competencies for a technical translator, linguistic competence in particular, which involves high-level knowledge of foreign languages (oral and writing skills), extralinguistic competence, which includes knowledge of subject areas, information and 
communication competence, which includes the ability to use the latest information technologies and methods of computer word processing.

In process of our scientific research, we have concluded that it is impossible to compare the content of translation master's programs component in the USA and Ukraine, as such training is not available in Ukraine. Despite the fact that the National Technical University of Ukraine "Kharkiv Polytechnic Institute" focuses on "the content of education of masters in vocational transaltion, based on the goals and society requirements for the system of knowledge, skills, abilities and competencies which are gained during the process of studying taking into account the prospects of science, technology and culture development and is determined by the educational-professional training program, curricula of disciplines" [5].

But we came to the conclusion that at US universities the training of specialists in vocational translation is aimed at high-quality technical, social-humanitarian, economic, professional and practical training, which is necessary for Ukraine.

Therefore, Ukraine needs vocational translation specialists with established professional competencies. It is concluded that there is the urgency of such specialists training in the context of Ukrainian integration into the European and world educational space. Establishments of high education in Ukraine prepare masters in translation, so it is possible to solve the problem of training masters in vocational (technical) translation by improving the training of masters of philology. The current direction of master's degree in philology preparation is focused on readiness for linguistic and cultural communication. These and other factors make it advisable to determine the conceptual basis for solving the problems of developing the professional competencies of a vocational (technical) translation specialist.

An important condition of progressive American experience in Ukrainian universities is the development of curricula and appropriate educational and methodological support, taking into account the principles systematicity and consistency, interactivity and clarity, integrity and electiveness, flexibility and individualization, practical and professional orientation.

A systematic analysis of the principles of future vocational translators training concluded that the Ukrainian education system lacks the following conditions for professional training of masters in vocational translation: the relationship of professional and humanitarian disciplines, professional, technical and scientific orientation in teaching translation, combining information and communication technologies with traditional forms of education, implementation of independent work of masters in technical translation.

These are the appropriate recommendations for improving the masters' vocational transaltion training in Ukrainian universities based on US experience, namely:

- develop guidelines for the implementation of educational programs for the preparation of masters in technical translation in collaboration with experienced technical translators, including the introduction of mandatory and elective courses in "Technical Translation" (e.g. "Terminology and computer programs for technical translators", "Translation of patent documents","Business Management for Translators", etc.);

- introduction the means of digital translation in process of vocational masters' training;

- ensuring academic mobility, international exchanges and internships for researchers, teachers and students in the field of vocational (technical) translation;

- creation of mechanisms for accreditation of educational programs for the preparation of masters in technical translation as interdisciplinary, improvement of certification of technical translators. 
Relevant recommendations will be useful for the preparation of masters in technical translation, given the need to develop the professional competence of technical translation specialists.

The experience and practice of training the masters in technical translation at US universities show that the main concept in the preparation of masters in technical translation is the creation of curricula with a subject specialization. We can state that a highly qualified technical translators in the labor market are specialists who have special theoretical and practical training in vocational translation, as well as in specialized technical courses, namely "Electrical Engineering", "Industrial Systems and Engineering", "Materials Science", "Mechanical Engineering", "Computer Science and Engineering ", etc. Therefore, it is advisable to introduce the specialty "Technical Translator" in polytechnic universities of Ukraine, for example, National Technical University of Ukraine "Kyiv Polytechnic Institute named after Igor Sikorsky", National University "Lviv Polytechnic", Central Ukrainian Technical University and Ternopil National Technical University named after Ivan Puliui.

\section{References}

Bobrova, S.; Mussaui-Ulianishcheva, E.; Ulianishcheva, L.; Popova, E.; Zakharova, E. (2017). “Major Approaches to Teaching a Foreign Language to Humanities-Based Students in the Context of Cultivating the Subject Component of Their Professional Development", Vol. 38 (Number 56), Page 6. Retrieved from: http://www.revistaespacios.com/a17v38n56/17385606.html

Byrne, J. (2009). "The coming of age of technical translation." The Journal of Specialized Translation. Issue 11. P. 2-5. Retrieved from: http://www.jostrans.org/issue11/art_introduction.php.

Gabr, M. (2001) "Toward a model approach to translation curriculum development." Translation Journal Vol. 5. (Number 4). Retrieved from: http://translationjournal.net/journal/16edu.htm.

Kastberg, P. (2002) "Information and Documentation Management in the Training of Technical Translators - As Opposed to Teaching Technical Science." LSP \& Professional Communication. Vol. 2. (Number 1.)

National Technical University «Kharkiv Polytechnic Institute» (2021), "Specialties and science programs". Available at: http://www.kpi.kharkov.ua/ukr/osvita/spetsialnosti-ta-spetsializatsiyi/

New York University School of Professional Available at: https://www.sps.nyu.edu/professionalpathways/topics/translation-and-interpreting/translation-studies.html

Shandruk, S.I. (2012), "Tendentsii profesiinoi pidhotovky vchyteliv v USA" [Teacher training trends in the United States], Kirovohrad State Pedagogical University named after V. Vynnychenko, Kirovohrad, Ukraine.

Tennent, M. (2005). "Training for the new millennium: pedagogies for translation and interpreting." John Benjamins Publishing Company.

Verkhovna Rada of Ukraine (2014), "Law of Ukraine "On Higher Education". Available at: https://zakon.rada.gov.ua/laws/show/1556-18\#Text

Esta obra está bajo una Licencia Creative Commons Attribución-NoCommercial 4.0 International

\section{(cc) $\mathrm{BY}-\mathrm{NC}$}

